MTPH Journal, Volume 4, No. 2, September 2020

\title{
EVALUASI SISTEM KEWASPADAAN DINI DAN RESPONS DEMAM BERDARAH DENGUE MENGGUNAKAN MODIFIKASI MALCOLM BALDRIGE DI KABUPATEN TRENGGALEK
}

\author{
Abdul Hakim Zakkiy Fasya, Agus Aan Adriansyah, Dwi Handayani \\ Program Studi Kesehatan Masyarakat, Fakultas Kesehatan, Universitas Nahdlatul Ulama Surabaya \\ Email: abdul.hakim@unusa.ac.id
}

\begin{abstract}
Early Warning Alert and Response System (EWARS) of DHF becomes an effort in the prevention and control of DHF cases in Trenggalek Regency. Unfortunately, the DHF case in Trenggalek Regency is still a public health problem. This study aims to evaluate the implementation of DHF EWARS using a Malcolm Baldridge modification, in the form of leadership, strategic management, knowledge management, resource focus, process management and results of the DHF EWARS implementation in Trenggalek Regency in 2017. It is an evaluative study through quantitative and qualitative approaches. Using a cross-sectional research design. The study was conducted in Trenggalek Regency, involving 37 respondents from the Dinas Kesehatan, Puskesmas and Jumantik Cadre. Some components had received a low score. The attention of the leadership on staff incentives, cadre understanding of the strategic plans and targets for dengue prevention, the use of technology that did not support the process and could not provide alerts, cadre satisfaction in reporting PJB and DHF cases, and a decrease in the number of cases that have not yet reached the target. There were still obstacles to the implementation of the DHF EWARS, so that the Trenggalek Regency government, especially the Dinas Kesehatan, could analyze the system requirements to support DHF EWARS reports, along with supporting the analysis of cadre's role and incentives are given to cadres and officers who excel in efforts to prevent and handle cases and DHF outbreak.
\end{abstract}

Keywords: EWARS, DHF, Malcolm Baldridge, Trenggalek Regency

\begin{abstract}
ABSTRAK
Sistem Kewaspadaan Dini dan Respons (SKDR) penyakit DBD menjadi sebuah upaya dalam pencegahan dan penanggulangan kasus DBD di Kabupaten Trenggalek. Sayangnya kasus DBD di Kabupaten Trenggalek masih menjadi masalah kesehatan masyarakat. Penelitian ini bertujuan untuk mengevaluasi pelaksanaan SKDR DBD menggunakan modifikasi Malcolm Baldrige berupa komponen kepemimpinan, manajemen stratejik, manajemen pengetahuan, fokus sumber daya, manajemen proses dan hasil pelaksanaan SKDR DBD di Kabupaten Trenggalek pada tahun 2017. Penelitian ini merupakan penelitian evaluatif melalui pendekatan kuantitatif dan kualitatif menggunakan rancang bangun penelitian cross sectional. Penelitian ini dilakukan di Kabupaten Trenggalek melibatkan 37 responden dari Dinas Kesehatan, Puskesmas dan Kader Jumantik. Hasil penelitian ini menunjukkan bahwa terdapat komponen yang mendapatkan skor rendah yaitu perhatian pimpinan pada insentif petugas, pemahaman kader terhadap rencana stratejik dan target penanggulangan DBD, penggunaan teknologi yang tidak mendukung proses dan tidak dapat memberikan alert, kepuasan kader dalam pelaporan PJB dan kasus DBD serta penurunan angka kasus
\end{abstract}


yang belum mencapai target. Terdapat hambatan pelaksanaan SKDR DBD sehingga pemerintah Kabupaten Trenggalek khususnya Dinas Kesehatan dapat melakukan analisis kebutuhan sistem untuk menunjang pelaporan SKDR DBD berikut dengan analisis penunjang berupa peran kader dan insentif yang diberikan kepada kader maupun petugas yang berprestasi dalam upaya pencegahan dan penanggulangan kasus dan KLB DBD.

Kata kunci: SKDR, DBD, Malcolm Baldrige, Kabupaten Trenggalek

\section{PENDAHULUAN}

Penyakit Demam berdarah dengue (DBD) banyak terjadi di daerah tropis dan sub-tropis. Kondisi di dunia menyatakan bahwa Asia menempati urutan pertama dengan jumlah penderita DBD pada setiap tahun. Indonesia sendiri menjadi negara dengan kasus DBD tertinggi kedua setelah Thailand di Asia Tenggara. Penyakit DBD masih menjadi salah satu masalah kesehatan masyarakat yang mendapat perhatian khusus di Indonesia. Jumlah penderita dan luas daerah penyebarannya semakin bertambah seiring dengan meningkatnya mobilitas dan kepadatan penduduk $^{1}$.

Penyakit DBD di Indonesia pada tahun 2016 terjadi sebanyak 204.171 kasus dengan jumlah kematian sebanyak 1.598 orang. Jumlah kasus DBD tahun 2016 meningkat dibandingkan jumlah kasus tahun 2015 yaitu sebanyak 129.650 kasus. Jumlah kematian akibat DBD tahun 2016 juga meningkat dari tahun 2015 yaitu sebanyak 1.071 kematian. Angka kesakitan DBD tahun 2016 juga meningkat dari tahun 2015, yaitu 50,75 menjadi 78,85 per 100.000 penduduk $^{2}$.
Kematian Case Fatality Rate (CFR) akibat DBD dinyatakan lebih dari $1 \%$, termasuk kategori tinggi. Pada tahun 2016 terdapat 11 provinsi yang memiliki CFR tinggi dimana Jawa Timur termasuk didalamnya, dengan CFR sebesar $1,40 \%^{2}$.

Pada tahun 2016 terjadi ledakan kasus DBD di Provinsi Jawa Timur, dimana beberapa kabupaten memiliki jumlah kasus lebih dari 1000 kasus termasuk salah satunya Kabupaten Trenggalek yang menempati 5 besar kabupaten di Jawa Timur dengan kasus DBD terbanyak, yaitu 1.159 kasus. Jumlah kasus tersebut meningkat hampir dua kali dari tahun sebelumnya dengan jumlah kasus sebanyak $677^{3}$.

Oleh karena itu, pemerintah mengupayakan pencegahan dan penanggulangan kasus DBD dengan Sistem Kewaspadaan Dini dan Respons (SKDR). SKDR dilaksanakan dengan pemantauan data epidemiologi yakni data mengenai populasi atau penduduk yang terkena KLB, khususnya kasus DBD sebagai upaya kesiapsiagaan, pencegahan, dan penanggulangan kasus DBD dengan cepat dan tepat ${ }^{4}$. 
Pelaksanaan KDR di Kabupaten Trenggalek sudah memenuhi target untuk kelengkapan pelaporannya yaitu sebesar $98,5 \%$ pada tahun 2016, dimana target untuk kelengkapan pelaporan sebesar 90\% laporan. Namun masih terdapat hambatan dalam ketepatan pelaporan sehingga masih mencapai 79\% dan belum memenuhi target, dimana target ketepatan pelaporan adalah sebanyak $80 \%{ }^{5}$.

Malcolm Baldrige adalah sejenis penghargaan tahunan yang diberikan oleh pemerintah Amerika Serikat melalui Department of Commerce kepada setiap organisasi di negara Amerika Serikat baik profit dan non-profit yang dianggap mencapai kinerja yang unggul dan excellent. Untuk menganalisis perkembangan pelaksanaan SKDR DBD di Kabupaten Trenggalek dengan menemukan hambatan pelaksanaan, Malcolm Baldrige dapat digunakan sebagai tools yang sesuai. Analisis berdasarkan kategori kepemimpinan hingga hasil pelaksanaan dapat menelusuri seluruh aspek sehingga dapat diketahui dengan jelas komponen apa saja yang perlu dilakukan peningkatan kinerja, pada akhirnya upaya pencegahan dan penanggulangan kasus DBD di Kabupaten Trenggalek melalui SKDR DBD dapat berjalan dengan baik ${ }^{6}$.

\section{METODE PENELITIAN}

Penelitian ini merupakan penelitian evaluatif dengan mengevaluasi pelaksanaan SKDR DBD di wilayah kerja Dinas Kesehatan Kabupwaten Trenggalek menggunakan tools Malcolm Baldrige. Penelitian ini dilaksanakan secara cross sectional dengan responden Penyakit Menular dan Staff SKDR DBD dari Dinas Kesehatan, Petugas Pencegahan dan penaggulangan DBD Puskesmas serta Kader Jumantik binaan Puskesmas. Responden diambil data dengan wawancara menggunakan instrumen yang berbeda sesuai dengan tingkat manajemen pelaksanaan. Persentase capaian skor berdasarkan kriteria Malcolm Baldrige yaitu: sangat berbahaya (0\%-27,5\%); berbahaya (>27,5\%-37,5\%), cukup berbahaya (>37,5\%$57,5 \%)$, cukup aman (>57,5\%-77,5\%), aman (>77,5\%-87,5\%); sangat aman (>87,5\%-100\%).

\section{HASIL DAN PEMBAHASAN}

\section{Hasil Penelitian}

\section{Faktor kepemimpinan}

Fokus bagaimana perilaku pimpinan dapat mendorong atau memfasilitasi pelaksanaan SKDR DBD dan kebijakan yang mengatur pelaksanaan SKDR DBD di Kabupaten Trenggalek.

Tabel 1. Faktor Kepemimpinan SKDR DBD Kabupaten Trenggalek.

\begin{tabular}{lll}
\hline No & \multicolumn{1}{c}{ Kriteria Perilaku Pimpinan } & Skor \\
\hline 1 & Menjelaskan visi, misi, budaya dan nilai & 83,3 \\
\hline 2 & Komitmen terhadap hukum dan peraturan & 79,2 \\
\hline 3 & Mendorong perilaku taat hukum & 75,0 \\
\hline 4 & Tanggap dan menindak lanjut pelanggaran & 75,0 \\
\hline
\end{tabular}




\begin{tabular}{llc}
\hline No & \multicolumn{1}{c}{ Kriteria Perilaku Pimpinan } & Skor \\
\hline 5 & Menciptakan lingkungan kerja nyaman & 75,0 \\
\hline 6 & Memberikan masukan dan bimbingan & 83,3 \\
\hline 7 & Mempertimbangkan pendapat petugas & 83,3 \\
\hline 8 & Meneruskan informasi penting & 83,3 \\
\hline 9 & Transparansi kebijakan & 83,3 \\
\hline 10 & Menjunjung tinggi kejujuran & 79,2 \\
\hline 11 & Pertanggungjawaban operasional dan keuangan & 75,0 \\
\hline 12 & Evaluasi pelaporan secara rutin & 75,0 \\
\hline 13 & Analisis pencegahan kasus & 81,3 \\
\hline 14 & Perencanaan anggaran pelaksanaan & 73,0 \\
\hline 15 & Meminimalkan dampak merugikan masyarakat & 75,0 \\
\hline 16 & Memperhatikan pemberian insentif & 66,7 \\
\hline 17 & Mendukung pelatihan dan insentif & 79,2 \\
\hline & Capaian Skor & 78,0 \\
\hline & Kategori Skor & Aman \\
\hline
\end{tabular}

Berdasarkan Tabel 1, diketahui bahwa skor kategori kepemimpinan dalam pelaksanaan SKDR DBD di Kabupaten Trenggalek termasuk dalam kategori aman. Kondisi tersebut menunjukkan bahwa secara umum sudah mendukung pelaksanaan SKDR DBD di Kabupaten Trenggalek. Namun pada indikator memperhatikan pemberian insentif mendapatkan skor terendah sebesar $66,7 \%$.

\section{Faktor manajemen stratejik}

Fokus kepada upaya penentuan strategi teknis, pengambilan keputusan dan pengaturan sumber daya untuk pelaksanaan SKDR DBD di Kabupaten Trenggalek

Tabel 2. Faktor Manajemen Stratejik SKDR DBD Kabupaten Trenggalek.

\begin{tabular}{llc}
\hline No & \multicolumn{1}{c}{ Kriteria Manajemen Stratejik } & Skor \\
\hline 1 & Perencanaan jangka pendek dan jangka panjang & 75,0 \\
\hline 2 & Proyeksi strategi target dan capaian & 81,3 \\
\hline 3 & Efektivitas pelaksanaan & 73,0 \\
\hline 4 & Penyusunan rencana pelaksanaan & 77,2 \\
\hline 5 & Penyampaian rencana stratejik penanggulangan DBD & 54,0 \\
\hline 6 & Penyampaian target penanggulangan DBD & 52,0 \\
\hline 7 & Analisis SWOT & 60,5 \\
\hline 8 & Dikumpulkan dan dianalisis data dan informasi secara berkala & 93,8 \\
\hline 9 & Pelaksanaan rencana yang disusun & 75,0 \\
\hline 10 & Sumber daya mendukung tercapainya pelaporan dan penempatan sudah & 64,7 \\
\hline & sesuai & 62,0 \\
\hline 11 & Pelatihan rutin Kader Jumantik & 69,9 \\
\hline & Capaian Skor & Cukup Aman \\
\hline
\end{tabular}


Berdasarkan Tabel 2, skor kategori hal ini terjadi karena pihak Dinas Kesehatan manajemen stratejik dalam pelaksanaan SKDR DBD di Kabupaten Trenggalek termasuk dalam kategori cukup aman. Kondisi tersebut menunjukkan bahwa secara umum sudah cukup mendukung pelaksanaan SKDR DBD. Namun pada indikator penyampaian rencana stratejik dan target penanggulangan termasuk dalam kategori cukup berbahaya. Menurut responden,

tidak pernah menyampaikan secara jelas terkait rencana stratejik dan target penanggulangan kasus DBD di Kabupaten Trenggalek.

\section{Faktor manajemen pengetahuan}

Fokus kepada tingkat pengetahuan petugas SKDR DBD terkait peran, wewenang dan tanggungjawabnya, termasuk pemanfaatan sarana dan prasarana pelaksanaan SKDR.

Tabel 3. Faktor Manajemen Pengetahuan SKDR DBD Kabupaten Trenggalek

\begin{tabular}{llc}
\hline No & \multicolumn{1}{c}{ Kriteria Manajemen Pengetahuan } & Skor \\
\hline 1 & Pemahaman SOP penanganan kasus DBD & 89,7 \\
\hline 2 & Pemahaman alur pelaporan SKDR & 89,7 \\
\hline 3 & Pelaksanaan pelaporan SKDR & 79,2 \\
\hline 4 & Respon cepat dan tepat kasus DBD & 83,3 \\
\hline 5 & Pelaporan data PJB lengkap & 100,0 \\
\hline 6 & Pelaporan PJB secara rutin & 100,0 \\
\hline 7 & Pelaporan kepadatan jentik & 100,0 \\
\hline 8 & Pelaporan kepadatan jentik rutin & 96,0 \\
\hline 9 & Kemudahan pelaporan PJB & 86,0 \\
\hline 10 & Tidak repot dalam pelaporan PJB & 87,0 \\
\hline 11 & Pelaporan PJB tidak mengganggu pekerjaan & 93,0 \\
\hline 12 & Data dan informasi lengkap untuk inovasi penanganan kasus DBD & 77,2 \\
\hline 13 & Data dan informasi aman dan sesuai kebutuhan & 79,2 \\
\hline 14 & Data dan informasi terbuka untuk diakses berbagai sektor terkait & 70,8 \\
\hline 15 & Penggunaan teknologi dan informasi & 56,3 \\
\hline 16 & Dalam keadaan darurat kasus DBD, sistem memberikan alert & 56,3 \\
\hline 17 & Pelatihan kader untuk penanggulangan penyakit DBD & 77,0 \\
\hline 18 & Kader memiliki sertifikat/ SK penugasan & 69,0 \\
\hline 19 & Kader tahu PJB untuk apa & 42,0 \\
\hline 20 & Pentingnya pelaporan PJB secara rutin & 52,0 \\
\hline & Capaian Skor & 79,2 \\
\hline & Kategori Skor & Aman \\
\hline
\end{tabular}

Berdasarkan Tabel 3, skor kategori mendukung pelaksanaan SKDR DBD di manajemen pengetahuan dalam pelaksanaan Kabupaten Trenggalek. Namun untuk beberapa SKDR DBD di Kabupaten Trenggalek termasuk faktor tertentu memiliki skor cukup berbahaya dalam kategori aman. Kondisi tersebut yaitu pada kriteria penggunaan teknologi dan menunjukkan bahwa secara umum sudah informasi, alert dari sistem, tujuan dilakukan 
PJB dan pentingnya pelaporan PJB secara rutin.

\section{Faktor fokus sumber daya manusia (SDM)}

Fokus kepada upaya menilai kebutuhan, kapasitas dan kemampuan petugas SKDR DBD di Kabupaten Trenggalek dengan melibatkan, mengelola dan mengembangkan SDM, termasuk membangun lingkungan kerja yang kondusif.

Tabel 4. Faktor Fokus SDM SKDR DBD Kabupaten Trenggalek.

\begin{tabular}{lll}
\hline No & \multicolumn{1}{c}{ Kriteria Fokus SDM } & Skor \\
\hline 1 & Penilaian kebutuhan, kemampuan dan kapasitas petugas & 68,8 \\
\hline 2 & Jumlah petugas Dinas Kesehatan sesuai & 75,0 \\
\hline 3 & Jumlah petugas Puskesmas sesuai & 68,8 \\
\hline 4 & Jumlah Kader Jumantik sesuai & 63,9 \\
\hline 5 & Sistem rekrutmen, seleksi, orientasi dan penempatan serta pendidikan dan & 70,8 \\
\hline 6 & latihan & 74,5 \\
\hline 7 & Pelatihan efektif & 66,7 \\
\hline 8 & Diskusi dengan Kader Jumantik tentang penyakit DBD & 72,0 \\
\hline 9 & Petugas dilibatkan perencanaan & 77,2 \\
\hline 10 & Petugas dilibatkan pemecahan masalah & 81,3 \\
\hline 11 & Petugas memberikan inovasi & 66,7 \\
\hline 12 & Tugas dan wewenang petugas sesuai dengan kemampuan & 70,8 \\
\hline 13 & Kompensasi, penghargaan dan/atau insentif bagi petugas yang berprestasi & 52,2 \\
\hline 14 & Petugas puas dengan pelaporan kasus DBD dalam SKDR DBD & 68,8 \\
\hline 15 & Kader Jumantik puas dengan pelaporan PJB dan kasus DBD & 55,0 \\
\hline 16 & Kader mendapat pelatihan sebelum ditetapkan sebagai Kader Jumantik & 84,0 \\
\hline 17 & Kader dilibatkan dalam kegiatan Puskesmas/ Dinas Kesehatan & 78,0 \\
\hline 18 & Kader dilibatkan dalam diskusi tentang penyakit DBD & 75,0 \\
\hline 19 & Kompensasi sudah cukup & 43,0 \\
\hline 20 & Kompensasi sesuai dengan tugas & 42,0 \\
\hline 21 & Kader mendapat penghargaan & 42,0 \\
\hline 22 & Kader mendapat pengakuan & 60,0 \\
\hline 23 & Kader merasa puas ikut serta dalam pelaporan PJB & 64,0 \\
\hline 24 & Kepuasan kader dalam pelaporan kasus penyakit DBD & 64,0 \\
\hline & Capaian Skor & 66,0 \\
\hline & Kategori Skor & Cukup Aman \\
\hline
\end{tabular}

Berdasarkan Tabel 4, diketahui bahwa skor kategori fokus SDM dalam pelaksanaan SKDR DBD termasuk dalam kategori cukup aman. Kondisi tersebut menunjukkan bahwa secara umum sudah cukup mendukung pelaksanaan SKDR DBD di Kabupaten
Trenggalek. Namun, beberapa faktor tertentu memiliki skor cukup berbahaya yaitu kepuasan kader jumantik terkait pelaporan PJB dan kasus DBD, kemudian kecukupan kompensasi, kesesuaian kompensasi dengan tugas yang diberikan, serta penghargaan atas keberhasilan. 


\section{Faktor manajemen proses}

Fokus kepada pemanfaatan kompetensi inti untuk mendesain, mengelola sistem, dan proses kerja dalam keadaan darurat DBD di Kabupaten Trenggalek serta kecepatan menghadapi perubahan.

Tabel 5. Faktor Manajemen Proses SKDR DBD Kabupaten Trenggalek.

\begin{tabular}{lll}
\hline No & \multicolumn{1}{c}{ Kriteria Manajemen Proses } & Skor \\
\hline 1 & SKDR memanfaatkan sumber daya secara efektif dan efisien & 73,0 \\
\hline 2 & Sistem kerja disususn berdasarkan rencana stratejik dan pedoman & 77,2 \\
\hline 3 & $\begin{array}{l}\text { Kegiatan operasional dikelola untuk mencapai target pelaporan dan } \\
\text { pencegahan }\end{array}$ & 75,0 \\
\hline 4 & $\begin{array}{l}\text { Menghadapi kedaruratan, Dinas Kesehatan menyiapkan pencegahan, } \\
\text { manajemen risiko, keberlanjutan operasional, evakuasi dan pemulihan }\end{array}$ & 89,7 \\
\hline 5 & $\begin{array}{l}\text { Input pelaporan menggunakan sistem yang otomatis merekapitulasi dan } \\
\text { menganalisis data }\end{array}$ & 52,2 \\
\hline 6 & Kader dilibatkan dalam upaya penanggulangan dan manajemen risiko & 70,0 \\
\hline 7 & Kader dilibatkan dalam upaya evakuasi & 63,0 \\
\hline 8 & Kader dilibatkan dalam upaya pemulihan & 51,0 \\
\hline 9 & Proses pelaporan dilaksanakan sesuai dengan pedoman & 60,5 \\
\hline 10 & Pemantauan dan peningkatan proses kerja petugas & 73,0 \\
\hline 11 & Proses kerja dirancang untuk meningkatkan kualitas pelaporan & 70,8 \\
\hline 12 & Proses kerja dirancang untuk kinerja yang lebih baik & 73,0 \\
\hline 13 & Proses kerja dirancang untuk penyerapan anggaran yang lebih baik & 56,3 \\
\hline 14 & Proses analisis dilaksanakan sesuai dengan panduan & 73,0 \\
\hline 15 & Respons cepat & 77,2 \\
\hline 16 & Terdapat teknologi yang memudahkan pelaporan & 37,0 \\
\hline 17 & Terdapat teknologi yang mudah dioperasikan & 37,0 \\
\hline & Capaian Skor & 65,2 \\
\hline & Kategori Skor & Cukup Aman \\
\hline
\end{tabular}

Berdasarkan Tabel 5, diketahui bahwa skor kategori manajemen proses dalam pelaksanaan SKDR DBD di Kabupaten Trenggalek termasuk dalam kategori cukup aman. Kondisi tersebut menunjukkan bahwa secara umum sudah cukup mendukung pelaksanaan SKDR DBD. Namun untuk beberapa faktor tertentu memiliki skor cukup berbahaya yaitu input pelaporan tidak menggunakan sistem otomasi, pelibatan kader dalam upaya pemulihan dan proses kerja untuk penyerapan anggaran. Terlebih terdapat faktor dalam kategori bahaya, yaitu tidak terdapat teknologi yang mudah dioperasikan dan memudahkan pelaporan.

\section{Faktor hasil}

Fokus kepada serangkaian proses kewaspadaan dini dan respons penyakit DBD, untuk mencegah terjadinya KLB DBD di Kabupaten Trenggalek. 
Tabel 6. Faktor Hasil SKDR DBD Kabupaten Trenggalek.

\begin{tabular}{lll}
\hline No & \multicolumn{1}{c}{ Kriteria Hasil } & Skor \\
\hline 1 & Kelengkapan pelaporan meningkat & 70,8 \\
\hline 2 & Ketepatan pelaporan meningkat & 73,0 \\
\hline 3 & Pelaporan SKDR DBD dilakukan dengan efektif dan efisien & 68,8 \\
\hline 4 & Strategi dan rencana kegiatan dapat diimplementasikan sesuai target & 66,7 \\
\hline 5 & Upaya berkelanjutan pencegahan dan penanggulangan kasus DBD & 79,2 \\
\hline 6 & Kendala pelaporan PJB dan kasus DBD dapat diatasi dengan baik & 62,5 \\
\hline 7 & Koordinasi lintas sector dapat berjalan dengan baik & 93,8 \\
\hline 8 & Terdapat inovasi dan kematangan upaya pencegahan dan penanggulangan & 75,0 \\
\hline 9 & DBD & 62,5 \\
\hline 10 & Kelengkapan pelaporan SKDR DBD mencapai target & 60,5 \\
\hline 11 & Ketepatan pelaporan SKDR DBD mencapai target & 54,2 \\
\hline 12 & Dalam 3 tahun terakhir tidak ada KLB DBD & 81,3 \\
\hline 13 & Dalam 3 tahun terakhir angka kesakitan menurun & 56,3 \\
\hline 14 & Dalam 3 tahun terakhir keparahan kasus menurun & 81,3 \\
\hline 15 & Dalam 3 tahun terakhir angka kematian menurun & 81,3 \\
\hline 16 & Angka kasus sudah menurun & 56,3 \\
\hline 17 & Puskesmas maupun Dinas Kesehatan menyampaikan kembali & hasil \\
& pelaporan & 85,0 \\
\hline & Capaian Skor & 71,1 \\
\hline & Kategori Skor & Cukup Aman \\
\hline
\end{tabular}

Berdasarkan Tabel 6, diketahui bahwa skor kategori hasil dalam pelaksanaan SKDR DBD di Kabupaten Trenggalek termasuk dalam kategori cukup aman. Kondisi tersebut menunjukkan secara umum sudah cukup mendukung pelaksanaan SKDR DBD. Namun, untuk beberapa faktor tertentu memiliki skor cukup berbahaya, yaitu adanya KLB DBD, angka kesakitan belum menurun sesuai target dan angka kasus belum menurun sesuai target.

\section{Pembahasan}

\section{Faktor kepemimpinan}

Pimpinan kurang memperhatikan insentif pada petugas pelaksana SKDR DBD. Mekanisme birokrasi Biaya Operasional
Kesehatan (BOK) yang mempersulit pimpinan untuk memperhatikan insentif/ reward kepada petugas pelaksana lapangan SKDR DBD. Kondisi birokrasi demikian yang menghambat pelaksanaan implementasi sebuah program ${ }^{7}$.

\section{Faktor Manajemen Stratejik}

Penyampaian rencana stratejik dan target penanggulangan kasus DBD kepada kader Jumantik tidak dilakukan oleh pihak Dinas Kesehatan. Sehingga kader belum memiliki pemahaman rencana stratejik dalam upaya penanggulangan kasus DBD. Demikian pula dengan target capaian. Padahal pelibatan kader jumantik tersebut akan memberikan kontribusi sangat banyak terhadap upaya pencegahan dan penanggulangan penyakit $\mathrm{DBD}^{8}$. 


\section{Faktor manajemen pengetahuan}

Masih terdapat hambatan pada penggunaan teknologi informasi untuk pelaporan SKDR DBD sehingga sistem yang seharusnya memberikan peringatan ketika dalam kondisi kasus yang berbahaya justru tidak terjadi. Akibatnya penanganan terhadap penderita dan kasus akan terhambat sehingga keparahan kasus akan meningkat. Analisis kebutuhan teknologi akan dapat menjawab kebutuhan sistem yang sesuai untuk diterapkan berdasarkan kondisi di kabupaten, baik dalam hal geografis, ketersediaan dan fungsi alat komunikasi, serta berbagai aspek lain yang mendukung pelaksanaan kewaspadaan dini dan respons terhadap penyakit $\mathrm{DBD}^{9}$.

Selain itu, terdapat masalah pada pengetahuan kader jumantik terhadap tujuan dilakukannya pemantauan jentik berkala (PJB) dan pentingnya pelaporan PJB secara rutin. Padahal pengetahuan yang tidak hanya teknik dalam melakukan PJB, akan membantu dalam penyuluhan dan penyebaran informasi kepada masyarakat akan pentingnya pelaksanaan PSN, sebagai upaya pencegahan penyakit $\mathrm{DBD}^{10}$.

\section{Faktor fokus sumber daya manusia (SDM)}

Terdapat hambatan pada kepuasan kader jumantik dalam menangani pelaporan dan pemeriksaan jentik. Hal tersebut terjadi karena adanya penolakan warga untuk diperiksa rumahnya. Kader jumantik sering menghadapi situasi tidak kondusif seperti penolakan dari pihak pemilik rumah. Alasan yang disampaikan yaitu kehadiran kader jumantik dianggap hanya mengganggu ${ }^{11}$.

Oleh karena itu, sebagaimana pembahasan poin sebelumnya terkait SK jumantik, perlu diberikan pemahaman kepada kader bahwa mereka memiliki legalitas untuk melaksanakan tugas sebagai kader jumantik, dimana tugas tersebut dalam rangka melaksanakan PJB dan penyuluhan terkait PSN kepada masyarakat ${ }^{12}$.

Mengingat wilayah kerja Puskesmas di Kabupaten Trenggalek cukup luas, maka petugas perlu mendapatkan motivasi untuk meningkatkan kinerja, dalam bentuk apresiasi maupun insentif. Demikian pula untuk kader jumantik, motivasi sangat dibutuhkan terutama bagi kader pada wilayah dengan kondisi geografis yang relatif lebih sulit setidaknya diberikan kompensasi dalam pelaksanaan PJB dan penyuluhan kepada masyarakat, dimana upaya yang dilakukan lebih besar dari pada Kader Jumantik yang berada di wilayah dengan kondisi geografis relatif mudah ${ }^{13}$.

\section{Faktor manajemen proses}

Input laporan yang menggunakan sistem murni hanya melalui SMS gateway dan langsung masuk ke dalam sistem pusat/ Kementerian. Sehingga pihak Puskesmas maupun Dinas Kesehatan tidak memiliki laporan. Sebaiknya dilakukan analisis kebutuhan teknologi informasi yang dapat mengakomodasi kebutuhan informasi yang akan digunakan sebagai acuan pelaksanaan kewaspadaan dini dan respons kasus DBD di kabupaten ${ }^{14}$. 
Kader jumantik dapat diikutsertakan dalam upaya evakuasi dan pemulihan lingkungan dan penderita DBD. Tentu dengan pembatasan bahwa apa yang dilakukan oleh kader diluar upaya medis. Pelibatan Kader Jumantik akan memberikan kontribusi sangat banyak terhadap upaya pencegahan dan penanggulangan penyakit $\mathrm{DBD}$, mengingat kondisi yang dijelaskan sebelumnya terdapat keterbatasan pada petugas dalam lingkup Puskesmas ${ }^{8}$.

Pemanfaatan teknologi yang mudah dioperasikan dalam mendukung proses pelaporan dapat memudahkan petugas untuk menyampaikan pelaporan dengan cepat dan tepat waktu ${ }^{15}$. Hambatan yang dialami selama melakukan proses pelaporan menggunakan formulir secara manual akan dapat diatasi dengan memanfaatkan fasilitas teknologi ${ }^{16}$.

\section{Faktor hasil}

Masih adanya kejadian luar biasa dengan meningkatnya jumlah kasus sebesar dua kali dari periode sebelumnya, kemudian terjadi penurunan angka kesakitan namun belum mencapai target yang ditetapkan dan penurunan angka kasus yang masih belum memenuhi target, terjadi karena adanya hambatan dalam kecepatan dan ketepatan pelaporan kasus $\mathrm{DBD}^{14}$.

Menurut petugas salah satu yang dikeluhkan adalah kondisi geografis setiap wilayah yang berbeda. Hambatan sering terjadi pada wilayah pegunungan dengan jarak antar rumah cukup jauh. Jarak yang jauh membutuhkan upaya yang lebih besar untuk melakukan PJB, sekaligus penemuan kasus penderita $\mathrm{DBD}^{17}$.

Selain itu, kondisi wilayah pegunungan memberikan kendala terhadap jaringan telekomunikasi. Bahkan beberapa wilayah tidak terjangkau signal jaringan telekomunikasi sehingga jika ada kasus, maka akan terlambat ditemukan dan terlambat dilaporkan ${ }^{18}$. Padahal pelaksanaan SKDR dengan modul SMS gateway dengan pusat data di Kementerian mengharuskan pelaporan menggunakan media SMS. Kondisi seperti ini memberikan hambatan dalam pelaksanaan ketepatan pelaporan SKDR. Sehingga pihak Kementrian sebaiknya melakukan pengkajian ulang terkait mekanisme pelaporan dengan modul SMS gateway ${ }^{14}$.

\section{SIMPULAN DAN SARAN}

\section{Simpulan}

Masih terdapat hambatan pelaksanaan SKDR DBD di Kabupaten Trenggalek berupa perhatian perhatian pimpinan terkait insentif petugas, pemahaman kader terhadap rencana stratejik dan target capaian upaya penanggulangan kasus DBD, ketepatan pelaporan akibat terbatasnya teknologi informasi yang menunjang, terutama pelaporan yang masih menggunakan SMS.

\section{Saran}

Pemerintah Kabupaten Trenggalek khususnya Dinas Kesehatan dapat melakukan 
analisis kebutuhan sistem untuk menunjang pelaporan SKDR DBD, berikut dengan analisis penunjang berupa peran kader dan insentif yang diberikan kepada kader maupun petugas yang berprestasi dalam upaya pencegahan dan penanggulangan kasus dan KLB DBD.

\section{REFERENSI}

1. RI K. Situasi penyakit demam berdarah di Indonesia tahun 2017. Infodatin Pus Data dan Inf Kementeri Kesehat RI Jakarta Kementeri Kesehat RI. 2018;

2. Kementrian Kesehatan. Profil Kesehatan. 2016. p. 100.

3. Jatim D. Profil kesehatan Jawa Timur tahun 2016. Dinas Kesehat Provinsi Jawa Timur Surabaya. 2017;

4. Kementerian Kesehatan RI. PMK no 949/MENKES/SK/VIII/2004 tentang Pedoman Penyelenggaraan Sistem KEwaspadaan Dini Kejadian Luar Biasa (KLB). 2004. p. 1-23.

5. Anggraini MP. Gambaran Early Warning Alert Response System (EWARS) di Dinas Kesehatan Kabupaten Trenggalek Tahun 2016. Universitas Arilangga; 2017.

6. Gasperz V. All-in-one 150 Key Performance Indicators and Balanced Scorecard, Malcolm Baldrige, Lean Six Sigma Supply Chain Management. Bogor Penerbit Tri-Al-Bros Publ. 2013;

7. Winengan W. Menakar Penerapan New Public Management dalam Birokrasi Indonesia. J Ilm Adm Publik. 2018;4(1):6674.

8. Adnan AB, Siswani S. Peran Kader Jumantik Terhadap Perilaku Masyarakat Dalam Upaya Pencegahan Penyakit Demam Berdarah Dengue (Dbd) Di Wilayah Kerja Kelurahan Tebet Timur Tahun 2019. JUKMAS J Untuk Masy Sehat. 2019;3(2):204-18.
9. Hamdani D, Virgana RAE. Perancangan Aplikasi Pemetaan Demam Berdarah di Kota Bandung Menggunakan Unified Software Development Process. J Teknol dan Inf. 2019;9(1):37-44.

10. Sukesi TW, Mulasari SA, Sulistyawati S. Penguatan jumantik di Patukan, Gamping, Sleman. In: Seminar Nasional Hasil Pengabdian Kepada Masyarakat. 2019. p. 23-8.

11. Yunita DS. Hubungan antara Pelatihan, Motivasi dan Ketersediaan Fasilitas dengan Partisipasi Jumantik di Kota Blitar. Indones J Public Heal. 2016;11(1):40-50.

12. Faizah A, Suryawati C, Fatmasari EY. Evaluasi Pelaksanaan Program Pengendalian Penyakit Demam Berdarah Dengue (P2DBD) Di Puskesmas Mojosongo Kabupaten Boyolali Tahun 2018. J Kesehat Masy. 2018;6(5):13-25.

13. Jannah I, Ridha A, Rochmawati R. Hubungan Pelatihan, Imbalan, Supervisi, dan Motivasi dengan Kinerja Kader Jumantik di Kecamatan Pontianak Timur Kota Pontianak. JUMANTIK J Mhs dan Peneliti Kesehat. 2020;6(2):42-9.

14. Afriyanty AY, Arso SP, Wigati PA. Analisis Kinerja Pelaksanaan Penyelidikan Epidemiologi Kasus Demam Berdarah Dengue Di Puskesmas Rowosari Kota Semarang Tahun 2017. J Kesehat Masy. 2017;5(4):15-22.

15. Finazis R, Syahrul F. Desain Alat Bantu Penunjang Laporan Sistem Kewaspadaan Dini Dan Respons Tingkat Puskesmas Kota Surabaya. Bul Penelit Sist Kesehat. 2018;20(3):105-13.

16. Masrochah S, Susanto E, Irmawati I. Sistem Informasi Pemantauan Kejadian Luar Biasa (Klb) Demam Berdarah Berbasis Geographic Information System (Gis) Di Kota Semarang. J Ris Kesehat. 2018;5(2):53.

17. Rini DS. Geographically Weighted Negative Binomial Regression untuk Jumlah Kasus Demam Berdarah Dengue 
MTPH Journal, Volume 4, No. 2, September 2020

ISSN: 2549-189X; e-ISSN: 2549-2993

Kabupaten/Kota Provinsi Bengkulu. In: PRISMA, Prosiding Seminar Nasional Matematika. 2018. p. 736-44.

18. Wulandhani S, Purnamasari AB, Pratomo RHS. Upaya Pencegahan dan Pengendalian Demam Berdarah Dengue dalam Bentuk Peta Tematik di Kecamatan Rappocini. bionature. 2019;19(2). 